\title{
UNA VIAJERA RUSA DEL XVIII EN LOS PIRINEOS FRANCESES ${ }^{(1)}$
}

\author{
Por Rafael OLAECHEA ALBISTUR \\ Universidad de Zaragoza
}

En cierta ocasión dijo Mme. de Staël que viajar era "el placer más aburrido". Dejando a un lado el hecho real de que la andariega baronesa aludia con estas palabras a una dura experiencia personal, podemos afirmar, sin ninguna exageración, que su célebre frase tenia plena vigencia en el siglo XVIII, y encerraba una realidad de lo más arriscada y azarosa, si se tiene en cuenta: el pésimo estado de los caminos, la incomodidad y lentitud de los carruajes, o la sordidez de los albergues y posadas, para no hablar de otros incidentes de mayor cuantía ocasionados por las tormentas, las averías de los carricoches, la falta de tiros en los lugares de posta, los latrocinios o el simple bandidaje(2).

Todo esto-dicho en sintesis-significa que viajar en aquella época, aun gozando de buena salud y disponiendo del mejor roulier, era sinónimo de padecer fatigas, de soportar una serie inevitable de contratiempos, y de exponerse en suma a sufrir las penalidades más imprevistas(3).

Los relatos de los viajeros de entonces ofrecen una pintoresca, a la par que inagotable, antología de ejemplos sobre este particular. Yo me ceñiré a presentar aquí algunos casos-no muy conocidos-en abono de lo que acabo de insinuar.

El embajador de España en París, don Carlos Gutiérrez de los Ríos, VI conde de Fernán-Núñez (1735-95), que sería testigo cualificado del estallido de la Revolución Francesa(4), llegó a la ciudad del Sena el 7 de octubre de 1787, después de un viaje no poco accidentado. Desde Bayona, donde tuvo que detenerse varias horas para reparar su carruaje seriamente 
averiado, escribió al conde de Floridablanca (1728-1808), ministro de Estado, las siguientes lineas: "Como los hermosos caminos de Vizcaya no se empedraron con cabezas de vizcainos, cedieron a los balanzos (sic) contínuos de los coches y carros, que los trillaban, y están convertidos en escaleras formales, de modo que no hay carruaje que los resista»(5).

El comediógrafo madrileño Leandro Fernández de Moratín (1760-1828) nos pinta sus peripecias de viajero con unos colores mucho más abigarrados. El 20 de abril de 1793 salió de Génova, a las 10 de la mañana, en compañía del diplomático español don Diego de La Cuadra, con la intención de digirse a Turin, a donde llegó tronzado el 23 a las seis de la tarde. EI ignoraba por completo que iba a necesitar más de tres días para cubrir una distancia de tan sólo $170 \mathrm{Kms}$. (unas 35 leguas); pero este pequeño «lapsus” de imprevisión queda perfectamente aclarado si se recuerda que, para hacer dicho viaje, el autor de El viejo y la niña comenzó por tomar "un coche derrengado, lleno de agujeros, goteras, parches y apósitos", que avanzaba a paso de buey por un camino que, al principio, era malo, luego peor y después impracticable. "Por último-escribe-, se atasca el coche, se sepultan los dos caballos en el lodo, el vetturino (cochero) reniega, y al cabo de media hora de un contínuo latigueo logra desengastar las dos alimañas; pero no consigue que el coche se enderece ni se mueva de donde está. Pues aquí de la prudencia del vetturino: desata sus caballos, márchase con ellos por el camino adelante, sin decir palabra, y nos deja dentro del coche en manos de la Providencia.

Cuando advertimos su fuga, ya estaba donde no podía oir nuestros alaridos: consulta, confusión de pareceres; pie a tierra. Llegamos a una casuca con el lodo hasta las rodillas, y lloviendo sin cesar; júntanse algunos payos hablando el piamontés, y pidiendo dinero a cada palabra; tráense cuatro robustos bueyes, y a fuerza de cuerdas, de voces y urgonazos sacan el coche del atolladero. Llegamos a un lugarcillo poco distante (...). El vetturino nos recibe con semblante halagüeño, que desarmó nuestra cólera, y como sea ya cosa averiguada y cierta que ningún vetturino es criatura racional, nos pareció más conveniente almorzar que reñir. Seguimos nuestro viaje; y al pasar por un torrente que venía furioso, para mi tuve que aquel era el cabo y remate de mis peregrinaciones. ¿Para qué (sirve) el mentir?. Mi virtud dominante es el miedo, y al verme alli tuve tantas razones de tenerle, que en mi vida me he visto más cercano de perecerw6).

Pero no acabaron aquí las desventuras de nuestro viajero, porque el 8 de mayo partió de Turín, a las 5 de la mañana, para dirigirse a Milán a bordo de una vettura, que iba «seguida de otros dos o tres carruajes, especie de caravana muy necesaria en aquella ocasión, por cuanto los caminos estaban poco limpios de ladrones. Al llegar al (río) Tesino-anota Moratin-, se pasa un bosque, famoso por los robos y asesinatos que en él se cometen frecuentemente: ya se deja entender el miedo con que yo paséw(7). 
Es un hecho historico comprobado que los salteadores de caminos (highwaymen) pululaban incluso en la civilizada Inglaterra, patria del humanitario bandolero Dick Turpin; no se trataba de asesinos vulgares, ni de ladrones sanguinarios, porque no mataban a los viajeros sino en última instancia-simplemente los desvalijaban-, pero sus asaltos a las diligencias eran tan frecuentes que esta «continuitè de vols-escribía el conde de Tilly-fasse naître les réflexions les plus désavantageuses à un gouvernement d'ailleurs si supérieurement conçu»(8).

Pero volvamos al relato de Moratin. "Durante el viaje-dice-nos juntábamos a comer en las posadas (en las cuales posadas comimos muy maly9) todos los viajeros que íbamos en los tres o cuatro coches mencionados. ¡Qué galeria de personajes!. Un genovés sórdido, con su mujer y su hija (horrendas las dos), que en vez de hablar ladraba (...). Un fraile muy gordo, sudando siempre, hablando con las mujeres de malos partos, destetes y preñados (...). Una mujerzuela con una chiquilla colgando de una teta (...). Una vieja ridícula, tan poco enseñada a viajar en coche, que en todo el camino no dejo de vomitar; y el fraile se esforzaba en persuadirla que todo aquello era mal de madre; $y$ así que llegábamos a las posadas empezaba a despanzurrar colchones, y a quemar lana para dar humazos a la vieja, de donde resultaba un pebete infernals(10).

Henos aquí, sin solución de continuidad, ante otra de las desagradables realidades que deparaban a los caminantes los viajes de aquella época: la sordidez de los albergues y posadas.

La archiduquesa austriaca M. ${ }^{2}$ Carolina (1753-1813) llegó a Nápoles en Mayo de 1768 para contraer matrimonio con Fernando IV (1751-1825), soberano de las Dos Sicilias. Al año siguiente recibió la visita de su hermano mayor, el futuro emperador José II (1741-90), que salió de Viena el 3 de marzo de 1769, y llegó a la ciudad de Nápoles el 31 del mismo mes.

En los informes que existen en el Haus-Hof-Staatsarchiv de Viena referentes a este viaje(11), se menciona con reiterado encomio un rasgo de "sencillez" del siempre original José II, es a saber: que tan augusto personaje accedió varias veces, durante el camino, a acostarse vestido y dormir sobre la paja, a falta de un lecho mejor(12). Con ser cierta la noticia, guardémonos, sin embargo, de conceder demasiada importancia a este rasgo "democrático" del príncipe austriaco; era más bien cuestión de higiene.

Todos sabemos que las palabras suelen renovarse como las hojas de los árboles; con el paso del tiempo, las mismas cosas son expresadas por vocablos distintos, y otras veces, una misma palabra sirve para designar realidades diferentes. Tal ocurre, por ejemplo, con la palabra hotel. Nosotros tenemos actualmente una idea muy determinada-quiero decir: 
confortable e higiénica-de lo que es, o puede ser, un establecimiento público de este género; pero en el siglo XVIII las cosas eran muy diferentes, empezando por la simple minucia de que entonces apenas habia categorias hoteleras: se desconocia el significado de las estrellas, y los mesones tampoco usaban el reclamo de los tenedores para indicar el nivel culinario-y crematístico-del menú.

Retrotraigámonos, pues, al XVIII y tendremos la oportunidad de encontrarnos con una intrépida viajera que, procedente de París, se alojó en agosto de 1784 en el flamante "Hotel de Saint Julien", de Nantes, cuya pulcritud dejaba, por lo visto, bastante que desear. "Nuestros lechos-refiere dicha señora-estaban plagados de chinches. Entre mi doncella y yo matamos sesenta; dos dias después desmontaron las camas, y se mataron cuatrocientas. Desde el comienzo de nuestro viaje jamás habiamos visto chinches en tanta cantidad.(13), confesión que tal vez pueda querer indicar, implícitamente, que en otros "hoteles" se habían dedicado a matanzas más discretas.

Todavía a finales del XVIII, encontrar en cualquier parte-o al borde de cualquier camino-un hotel con una habitación particular y su correspondiente cama, era un lujo que no podía permitirse cualquier persona. Por otro lado, si nos asombra un tanto la capacidad de aguante que movilizaban aquellas gentes ante este hecho (para nosotros insólito, pero para ellos habitual), debemos tener en cuenta que tanto la promiscuidad, como el respirar olores mefíticos o la costumbre de escupir en cualquier sitio(14), (para no mencionar-intencionadamente-otras funciones corporales y otros "alivios" somáticos más groseros), eran unos usos sociales tan comunes, que no herían la sensibilidad de las gentes de entonces, porque no traspasaban lo que el historiador $\mathrm{N}$. Elias ha llamado acertadamente uel umbral del pudorw(15).

Como en no pocos albergues y posadas, la sala principal o el zaguán de entrada (que servian de comedor durante el dia), estaban provistos de camas adosadas a las paredes, al llegar la noche se abatían, y aquellos recintos quedaban convertidos en un dormitorio general donde reposaban los viajeros de ambos sexos. Descartando-por supuesto-las posadas modestas o los albergues rústicos, como aquel en que Mme. de Sévigné no encontró más lecho que el heno fresco, "sobre el cual-dice-nos acostamos vestidos", algo similar ocurría en otros «hoteles" de más viso, donde el número de camas solía ser inferior al de huéspedes, sobre todo si se trataba de un lugar con relevo de postas. De ahi la necesidad inesquivable de dormir a veces en compañía de un desconocido.

La expresión "mal compañero de cama" o "ceder media", que encontramos en nuestra literatura picaresca, o en los informes de los hospitales públicos(16), no se tomaba entonces en sentido figurado, sino a la letra, ya que si alguien, por un sentimiento humanitario, o instado perento- 
riamente por el posadero, ofrecía la mitad de su lecho a un viajero retrasado, nervioso o roncador, se exponía a pasarse en blanco el resto de la noche. De ahí, también, el que muchos viajeros prefirieran ir al pajar; al menos allí se podía dormir con más desahogo, y sobre heno limpio, pues no está de sobra señalar de pasada, que las sábanas de las camas del zaguán solian estar cosidas al colchón, y sólo se mudaban cuando empezaban a adquirir tonalidades de color nicotínico.

Dada la indole de estas páginas, parece supérfluo acumular más ejemplos para poner de relieve la variada gama de percances que acechaban entonces a los viajeros que se lanzaban audazmente a transitar ya sea por los caminos de España, ya por los de otras naciones europeas(17), porque, sacadas fuera las excepciones, y hablando en general, puede afirmarse sin ninguna temeridad que, todavia a finales del XVIII, y pese a la "política de los caminos" practicada por los Gobiernos más civilizados, el estado general de las rutas era, en todas partes, igualmente detestable.

Digamos para concluir este apartado, que un hecho destaca meridianamente en este escenario coruscante, y es: que basta seguir los itinerarios-y las peripecias-de los viajeros del XVIII para convencerse de que viajar en aquel tiempo no era, a lo que parece, ningún agradable esparcimiento, y que el hacerlo en semejantes condiciones tampoco ofrecía el menor aliciente para cultivar el turismo, como no sea que exceptuemos a una parte de la gentry británica, que empezó a poner de moda este fenómeno humano llamado a adquirir tan gigantescas dimensiones. Hablando en general, el mismo J. J. Rousseau señalaba, a este respecto, que, en su tiempo, eran los nobles ingleses quienes viajaban "turísticamente", mientras que en Francia la aristocracia se quedaba en casa, siendo personas de otros estamentos inferiores las que de ordinario viajaban de esta guisa.

\section{EL VIAJAR COMO FENOMENO SOCIAL}

Una vez aqui, alguien podría preguntar si unas perspectivas tan poco halagüeñas fueron capaces de arredrar a las gentes del XVIII, hasta el punto de quitarles el coraje para salir de sus casas a recorrer los caminos. La respuesta a este interrogante es, desde luego, negativa; más aún, teniendo en cuenta todas las circunstancias adyacentes (eso que nuestros entendidos Ilaman "estructuras coyunturales»), cabe decir-sin establecer ninguna comparación con la movilización del mundo actual-que el número de personas que, por las razones que fuera (incluida la naciente ratio turistica), se ponían entonces en camino, además de ser relativamente muy considerable, fue siempre en aumento con el paso del tiempo, entre otras razones (además de las demográficas y las utilitarias), porque el siglo XVIII no 
sólo descubrio, por así decirlo, sino que impuso la moda de viajar. Y es bien sabido que la moda, a cualquier escala, es "una rabia, una furia»18) que hace verdaderos estragos.

El ya citado conde de Tilly, famoso por sus aventuras galantes, escribia en 1788 como verdadero hijo de su tiempo: «Je me sentais un besoin impérieux de voyager; j'ai eu trop le temps et l'occasion depuis de satisfaire à cette fantasie; mais alors (que sólo tenía 24 años de edad), c'était je ne sais quoi d'inexplicable qui m'agitaitw(19). Pero idénticos impulsos de viajar sentían otros coetáneos suyos.

Este fenómeno histórico incontestable; y de no pequeña envergadura viene corroborado, desde otro ángulo, por el famoso viajero Lorenzo Sterne (1713-68). Si abrimos las páginas de su Viaje sentimental (1768), encontramos que el inquieto clérigo irlandés, no contento con hacer-como Moratín-la descripción de algunos de sus compañeros de camino, establece una curiosa clasificación entre: "Viajeros ociosos; viajeros curiosos: viajeros vanidosos; viajeros melancólicos. A continuación-escribe-vienen los viajeros por necesidad: viajeros felones y delincuentes, viajeros inocentes e infortunados, simples viajeros. $\mathrm{Y}$, finalmente, con vuestro permiso: el viajero sentimental, o sea yo (...), que ha viajado apremiado por el imperio de la Necessity and besoin de voyager (sic) en igual grado que cualquiera de los incluidos en esta categorias(20).

Este modo pintoresco de registrar la variedad de los viajeros no es un simple rasgo de humor inglés, sino una realidad tangible, y por otro lado, tal constatación constituye una forma indirecta de responder a la pregunta inicial, referente a si los peligros inherentes a los caminos frenaban el ánimo viajero de aquellas gentes.

Pero todavia puede darse otra respuesta complementaria para esclarecer esta cuestión, y para ello vamos a establecer una doble distinción. La primera de ellas se refiere a las diferencias existentes entre los viajes interiores y los exteriores; la otra distinción alude a ciertos matices obvios que contraponían el acto o, si se quiere, la empresa de viajar «roussonianamente", al simple hecho de recorrer los caminos. Comencemos por esta segunda.

a.-Es evidente que los hombres han viajado en todos los tiempos y lugares; pero en el siglo XVIII la tarea de viajar se fue convirtiendo, para cierta clase de personas (las que Gaspar Gomez de la Serna ha Ilamado atinadamente "viajeros de la llustraciónn), en una operación importante no sólo desde el punto de vista sociológico, sino en cuanto que tal menester constituyó otra manifestación más del despliegue intelectual del «Siglo de las Luces". No es, pues, extraño que el marqués de Pézai, consciente de este fenomeno, llegara a escribir en 1783, que los auténticos viajeros eran a los Filósofos lo que los boticarios a los médicos, ya que "los Filosofos-decía-apoyan sus sistemas en los relatos de los viajeros»(21). 
No todos los itinerantes, incluso muchos que presumían ser unos consumados viajeros, recorrían los caminos con arreglo a un plan previo, elaborado cuidadosamente; para ellos, el viajar no pasaba de ser un elegante errabundaje. Pero los viajeros que se ajustaban, de alguna manera, al esquema establecido por J. J. Rousseau en el Emile, solían ponerse en marcha no sólo-o no tanto-para ver tierras, paisajes, monumentos y paisanajes, como para conocer pueblos, estudiar costumbres y comparar las formas de gobierno de los distintos países.

Resulta interesante constatar, a este respecto, que fue el propio J. J. Rousseau- "gran errabundo" a su vez-quien encomió este sentido utilitario de los españoles sobre los demás viajeros de su tiempo, ya que adoctrinando a su pupilo le decia, no sin cierta exageracion: "Je ne connais guère que les Espagnols qui voyagent de cette manière (prestando toda su atención a lo que es verdaderamente útil)... Tandis qu'un Français court chez les artistes d'un pays (...), l'Espagnol étudie en silence le goubernement, les moeurs, la police, et il est le seul (entre un francés, un inglés y un alemán) des quatre qui, de retour chez lui, rapporte de ce qu'il a vu quelque remarque util à son pays»(22).

Como se deja entender, este modo de viajar-pragmático o científico-estaba reservado a un exiguo número de personas más o menos cultivadas; el resto de las gentes emprendían los viajes por imperativos políticos (militares o diplomáticos), por asuntos comerciales o administrativos, por razones pedagógicas, familiares y también amorosas, 0 simplemente por motivos de salud, pero raramente por placer; incluso la mayoría de los miembros del cuerpo diplomático de entonces (que recorrian largas distancias para llegar a sus respectivos destinos, y permanecian en ellos durante varios años) no tenían miras más altas al ponerse en camino, y por lo mismo no se preocupaban de convertir sus traslados en "viajes ilustrados".

No sólo por exigencias de tipo estratégico y económico, o bien para aumentar el aforo del comercio y agilizar la distribución de los productos y mercancías, sino por razones meramente sociales-amén de las politicas-, los Gobiernos de las naciones más civilizadas se hicieron eco de los problemas planteados por la creciente ola de personas que se veian obligadas a trasladarse de un lugar a otro; los afrontaron seriamente, y trataron de darles una solución eficaz, construyendo para ello nuevos caminos, y mejorando la red de comunicaciones.

Para ceñirme únicamente a España que fue con Fernando VI (1746-59), y sobre todo durante el reinado de Carlos III (1759-88), cuando empezó a implantarse en la Península ibérica, de una manera organizada, aunque muy lenta, la llamada "política de los caminos".

El ministro de Estado, don Ricardo Wall (1754-63), que ocupaba al mismo tiempo el cargo de Superintendente de Correos, nombro en 1755 asesor 
jurídico de dicho cuerpo al abogado asturiano don Pedro Rodriguez Campomanes (1723-1802), quien se dedicó con ahinco al conocimiento y fomento ("policia») de este importante ramo de la administración pública, y en 1761 dedicó al ministro Wall un detallado "Itinerario de las carreras de postax(23). En él recogio todo lo que estaba ya legislado sobre este sector, añadiendo importantes mejoras y sugerencias, de suerte que este escrito no sólo sirvió de base a las Ordenanzas de Correos, promulgadas por Carlos III el 23 de julio de 1762(24), sino que constituyó, por un lado, el primer reglamento encaminado a uniformar el trabajo de los empleados en las estafetas y postas de todo el reino (desde los administradores e interventores hasta los oficiales y los postillones), y, por otro, se convirtió en una especie de Guía o Baedecker muy útil para que los viajeros conocieran las vías de comunicación, las distancias que separaban las poblaciones, los precios de las postas y la legislación correspondiente. Actualmente, esta obra de Campomanes sigue teniendo un innegable valor históricogeográfico, como fuente de conocimientos del estado de las comunicaciones de España a mediados del XVIIII. La "política de los caminos» se habia puesto en marcha.

El conde de Floridablanca, ministro de Estado y Superintendente General de Correos desde 1777 hasta 1792, no hizo sino desarrollar este servicio público (poco fomentado por su antecesor el marqués de Grimaldi), con la particularidad de que la llamada "política de los caminos" se fue convirtiendo durante su ministerio en "política de caminos, puentes y posadas»(25), para no hacer mención de los canales, los puertos y los pantanos.

En un Memorial justificativo, que Floridablanca presentó al rey Carlos III el 10 de octubre de 1788, decia el ministro que, gracias a la participación de los mismos municipios, y a la colaboración desinteresada de algunos prelados munificentes, durante los nueve años que llevaba al frente de la Superintendencia de Correos, se habian construido en España más de 200 leguas de caminos nuevos(26), y pasaban de 300 las leguas de caminos arreglados o reconstruidos; se habian erigido, además, 322 puentes nuevos y habilitado otros $\mathbf{4 5}$ más para el tráfico rodado. Cada legua de camino estaba al cuidado de un peón caminero, con un capataz o celador cada ocho leguas, y en todo el reino se habian levantado, para estos mismos camineros, 49 casas nuevas, que eventualmente servian de refugio a los viajeros accidentados. Todo lo gastado en esta empresa de "policía general" rebasaba los noventa millones de reales(27).

Floridablanca aplicó al fondo de rentas del cuerpo de Correos el producto de las Gacetas y la contribución de la sal (sólo ella ascendio a 27 millones de reales en nueve años), amén de otros tributos destinados a la Hacienda; envió técnicos al extranjero al objeto de implantar en España los adelantos y mejoras que observaran en los demás países, tocantes a 
"este ramo de la policía general»; concedió toda clase de ventajas-sin excluir primas y gratificaciones-a cuantos españoles fomentaran las facilidades para viajar con mayor comodidad; aumento considerablemente el número de postas y de estafetas de correos por toda el área de la geografía hispana; uniformó las tarifas de los viajes para evitar exacciones y timos, y hasta llegó a reglamentar, en cada población importante, los lugares y las horas de salida-ya que no las de llegada-de las diligencias públicas y de los servicios regulares, sin perjuicio, naturalmente, de que las personas pudientes, o urgidas por la prisa, pudieran valerse de otros medios de locomoción, o viajar en coches de su propiedad.

Los puntos de salida y de llegada de las diligencias públicas (que equivalian, en cierto modo, a nuestras actuales estaciones de ferrocarril) eran muy concurridos, y solían estar frecuentados por gentes de toda clase y condición; el alboroto de los viajeros y los gritos de los postillones, los abrazos de bienvenida asi como las lágrimas de despedida formaban, con el restallido de los látigos y el ruido ensordecedor de los carruajes, una parte esencial de la escena, que para unos era un espectáculo municipal, y para otros un "divertimenton. Los pisaverdes y lechuguinos se plantaban en las cercanias para ver el tobillo de alguna damisela que subia al coche, y en un lugar populoso y trajinero como este es donde el caballero don Grieux conocio a la joven Manon Lescaut (1733).

b.-Hasta aquí nos ha conducido la exposición de algunas diferencias existentes entre el simple hecho de recorrer los caminos (faena que realizaban innumerables personas), y el viajar "roussonianamente" (que era una empresa de minorias); muy de pasada hemos aludido también a la "política de los caminos" del Gobierno español durante la segunda mitad del XVIII.

Pero todavía queda pendiente el abordar la primera distinción que haciamos más arriba entre los viajes interiores y los exteriores, o dicho con otras palabras: entre los viajeros que no transponian las fronteras de su patria y los que salian al extranjero, bien entendido que en uno y otro caso tomamos la palabra "viaje» en la acepción-más o menos restringida-de "viaje ilustrado", y no como un simple recorrido de leguas y caminos.

Por lo que respecta a los "viajes interiores", el citado G. Gómez de la Serna ha descrito, en un libro delicioso, las características-y las motivaciones-de un puñado de españoles cultos que realizaron unos ejemplares "viajes ilustrados" por el interior de su patria; simultáneamente, ha trazado también una tipología provisional de los itinerarios-geográficos y mentales-seguidos por estos «viajeros de la llustración", y los ha clasificado (sin ningún orden de prelación) en cinco categorías: 1. Viajes económicos, como los de B. Ward y G. Bowles; 2. Viajes cientifico-naturalistas, como el del benedictino P. Sarmiento a 
Galicia en 1745, y el viaje botánico-geográfico del abate A. J. Cavanilles al reino de Valencia; 3 . Viajes artísticos, el más famoso de los cuales fue el de don Antonio Ponz'(28), sin olvidar por ello los de A. Vargas Ponce, I. Bosarte y J. Ortiz; 4. Viajes histórico-arqueológicos, cuales fueron los del marqués de Valdeflores, de F. Pérez Bayer, y de Jaime Villanueva, hermano éste último del famoso canónigo J. L. Villanueva; 5. Viajes literariosociológicos, entre los cuales hay que poner el del agustino P. Florez, el del abate J. de Viera y Clavijo, que también viajó por Europa, y el de Tomás de Iriarte a la Alcarria, para no citar otros autores ${ }^{(29)}$. Sin ánimo de ofender, ni de enmendar la plana a nadie, aún se podian añadir a los anteriores los Viajes políticos, como los del comisario Francisco Zamora, confidente del favorito Manuel Godoy, y los Viajes pintorescos, especie de itinerarios histórico-descriptivos, que resultan ser los de Jovellanos, $y$-aunque francés-los de Alejandro de Laborde.

El gran hispanista francés J. Sarrailh, al que me complazco en citar en esta ocasión, se intereso no poco por los relatos de los viajeros del XVIII(30), y ello-entre otras razones-porque él consideraba este género literario no sólo como una floración típica del setecientos, al mismo tiempo que una plataforma orientada hacia el futuro, sino como una vía peculiar de aproximación al conocimiento-en este caso-de la sociedad española de aquella centuria. Nada tiene, pues, de extraño, y sí mucho de natural, que Sarrailh dedicara dos capítulos de su copiosa obra sobre «La España llustradan a estudiar la manera-o una de las maneras-cómo los españoles de la segunda mitad del XVIII podían adquirir un conocimiento adecuado del extranjero, para aplicar luego en su patria las enseñanzas venidas de fuera o aprendidas allende los Pirineos $(31)$.

El primero de estos capítulos está consagrado «al extranjero en España", y su contenido rebasa el área de estas páginas, en primer lugar, porque en él se trata de cosas y personas extranjeras-principalmente francesas-llegadas a España, y no de viajeros españoles, tema que, con una excepción(32), centra el contenido de la presente comunicación; y en segundo término, porque los relativamente pocos extranjeros que venian entonces a España eran-a juicio del citado Laborde-unos viajeros ocasionales, que miraban las cosas a través de sus gafas negras, deformaban maliciosamente la realidad, y se burlaban casi siempre del atraso y de las "bizarras originalidades" de nuestro singular pais.

Todos estos puyazos - los chistes irónicos, las mentiras más descaradas, cuando no los errores más crasos, vertidos intencionadamenteproducian la justa indignación de los españoles cultos, y en alguna ocasión provocaron la intervención oficial del Gobierno de Madrid, como ocurrio, por citar un caso, con el infamatorio "Viaje de Fígaro a España", del falso marqués de Langle, nombre con el que se cubria un libelista francés que muy probablemente jamás puso sus pies a este lado de los Piri- 
neos(33). Por otro lado-añade Laborde-, “España se contó durante mucho tiempo en el número de los países olvidados; como no se encuentra en el camino de ningún otro reino (a excepción de Portugal), fue dejado de lado y no entró en los itinerarios de lo que los ingleses llaman wel gran viaje" (the grand tour), que dura (unos) dos años y que, entre ellos, forma parte de la educación de los ricos, con el mismo derecho que la retórica y la filosofían(34), ya que tal viaje venia a ser-y se pretendía que fuera-como el remate de la educación de todo joven aristócrata inglés.

En cambio en el segundo capitulo, Sarrailh habla eruditamente del "español en el extranjero", y con esta aportación trata de completar el tema desde esta otra vertiente.

$Y$ digo que "trata" (sin conseguirlo del todo), pues su exposición se me antoja-y es una opinión puramente personal-un tanto limitada, por falta de casuística, ya que solamente recoje en su obra los ejemplos de contados españoles, viajeros por el centro de Europa, sin tener en cuenta otros muchos casos análogos, y no menos interesantes que los citados por él, cual es, por ejemplo, el del abate santanderino M. A. de la Gándara (171883), agente general de preces en Roma, y autor de unos interesantísimos "Apuntes sobre el mal y el bien de España", someramente analizados, con voz de alerta, por el gran hispanista G. Desdevises du Dézert, para no referirnos a la pléyade de viajeros españoles que, por distintos motivos, visitaron la península italiana(35).

Este arbitrio selectivo-intencionado o no-, utilizado por Sarrailh en este capítulo, puede producir en el lector poco avisado la impresión de que los españoles del XVIII sólo viajaban a Francia, como si únicamente allí pudieran adquirir conocimientos útiles para su patria. Es cierto que, para los españoles de entonces, Francia solia constituir la meta preferente de sus itinerarios, pero este dato cuantitativo-a la par que objetivo-no invalida el que otro número menor (pero mayor que el aducido por Sarrailh) visitara también otros países europeos que no eran necesariamente "la douce France».

Dos móviles, de importancia desigual, parece que impulsaron a no pocos españoles del XVIII a salir de la Peninsula para conocer el extranjero, y concretamente el reino de Francia. Los más adinerados-que eran a su vez los menos numerosos-cedieron sin duda a la creciente moda de viajar; pero la mayoria se puso en camino impulsada por móviles utilitarios, fueran éstos de tipo pedagógico, diplomático, científico, profesional, económico-comercial, artístico, medicinal o sentimental.

Aparte de algunos hijos de diplomáticos españoles, acreditados en las distintas Cortes europeas, no faltaron en España jóvenes de la aristocracia que, a imitación de los ingleses, hicieron también su "grand tour» por Europa, acompañados de un preceptor idóneo. Tales fueron los casos 
de Carlos Gutiérrez de los Ríos, futuro VI conde de Fernán Núñez; del hijo del marqués de Santa Cruz, que viajó en compañía del citado José de Viera(36); y del guipuzcoano Ramón Muribe, hijo del conde de Peñaflorida, que se desplazo hasta Escandinavia, acompañado por el abate Cluvier, siendo de lamentar que las carraspeantes cartas escritas, en tal ocasión, por el procer guipuzcoano a su pródigo retoño no tengan el encanto y la fina sabiduría mundana de las que lord Chesterfield dirigio, por aquel entonces, a su hijo mayor, viajero asimismo por el continente europeo.

Lo mismo antes que después de la expulsión de los jesuitas (1767), que habian detentado hasta esa fecha poco menos que el monopolio de la enseñanza media en España, no pocas familias, sobre todo del País Vasco, enviaban a sus hijos a Francia para que completaran allí su educación. Así es como el propio conde de Peñaflorida, otro vasco llamado Miguel de Olaso, y José Olazábal de la ciudad de San Sebastián-para ceñirme a tres casos que podrían multiplicarse-pasaron varios años en el colegio de los jesuitas de Tolouse, donde estudiaron ciencias físicas. Asi se explica, al menos en principio, el hecho cultural de que el conde de Peñaflorida, miembro integrante de "los aldeanos críticos", entrara en 1758 a polemizar con el autor del Fray Gerundio.

Algunas comunidades religiosas de Pau, preparadas para desempeñar decorosamente cierto tipo de tareas pedagógicas, solían recibir a un gran número de señoritas españolas, que iban allí a aprender la lengua de Molière, y a uformarse en las maneras francesas". El Parlamento del Bearne pidió en 1765 «un buen pensionado para los jóvenes", y años más tarde, las municipalidades de Pau y de Oloron hicieron lo propio, recordando la costumbre que tenian los españoles de acudir alli para instruirse, por to que solicitaban encarecidamente que se fundaran en dichas poblaciones sendos colegios con internado(37).

Después del Tercer Pacto de Familia (1761), el Colegio de Sorèze abrío sus puertas a jóvenes cadetes españoles. El "libro de entradas" de este centro, dirigido por religiosos, registra los nombres de los 86 caballeros españoles que fueron allí, desde 1761 a 1790 , para estudiar ciencias y formarse en el arte militar, además de aprender equitación y esgrima. Los cadetes españoles que acudian a Sorèze desde Madrid, Zaragoza, Barcelona, Málaga, Bilbao, Lugo y otros puntos de la Península ibérica, eran, en general, jóvenes de la pequeña nobleza; entre ellos encontramos a los dos hermanos Angel y Camilo Gutiérrez de los Rios, hijos naturales-legitimados-del mencionado VI conde de Fernán-Núñez, que los llamaba "mis dos pelendengues", por haberlos tenido de sus amores con una bailarina boloñesa, Ilamada Gertruda Marcucci, (a) la Galguilla, que en 1769 fue al Sitio Real de Aranjuez con una farándula de cómicos y cantantes franceses(38). 
A través de estas indicaciones sumarias podemos concluir, sin demasiado error, que las molestias y peligros anejos a los viajes no fueran óbice para impedir que muchas gentes del XVIII se lanzaran a recorrer los caminos, antes muy al contrario; y por lo que atañe a su número, si dejamos aparte a los viajeros de otras naciones europeas, y nos fijamos únicamente en la variada gama de españoles que, de paso o de asiento, iban entonces a las distintas regiones de Francia, y sobre todo a París, nos encontrariamos con una larga lista formada por diplomáticos, cónsules, pensionistas del Gobierno, agentes comerciales, artistas, literatos, profesores, estudiantes, técnicos, curiosos, artesanos y fabricantes bien acomodados, que viajaban por propia iniciativa para perfeccionar las técnicas de su oficio, y finalmente los enfermos aquejados por distintas dolencias.

\section{BARBARA JULIANA VIETINGHOFF DE KRUEDENER}

A esta última categoría pertenecian los acaudalados viajeros españoles y extranjeros-incluidos los americanos-que solían acudir entonces a los distintos balnearios de los Altos Pirineos franceses, ya sea para recuperar fuerzas o para curarse de algún mal específico.

Pero, ¿por qué se dirigían a estos establecimientos termales, tan apartados del mundo, y no a otros centros similares de más fácil acceso?. Sin duda alguna, por dos razones complementarias: la primera y principal, por la virtud curativa de sus aguas, acreditada desde el tiempo de los Romanos; y la segunda, por el exotismo de aquellos lugares y la salubridad de los aires de alta montaña, amén de la buena cocina que caracterizaba-para lo que entonces se estilaba en general-a los albergues emplazados cerca de los manantiales sulfurosos.

La gente de entonces (para no hablar de la de después), depositaba gran fe en la energía curativa de las aguas termales. Además del natural instinto de conservación, ello se debía en parte al poderoso influjo de la moda creciente, no menos que al crédito que ciertos médicos prestigiosos - no me refiero aquí a los médicos empíricos o practicones de las ciudades(39) - concedían entonces a cualquier tipo de hidroterapia, pues la consideraban como un remedio casi infalible para el tratamiento de determinadas enfermedades.

El 11 de junio de 1784, anotaba en su "carnet" de viaje la baronesa d'Oberkirch (1754-1803): "Un hecho muy extraño, pero muy verdadero, es lo mucho que este siglo, el más inmoral que ha existido, el más incrédulo, el más filosóficamente fanfarrón, se vuelve, en sus postrimerías, no a la fe, sino a la credulidad, a la superstición, al amor a lo maravilloso (...). Si miramos a nuestro alrededor, no vemos más que hechiceros, ocultistas, nigromantes y profetas. Cada uno tiene el suyo y se apoya en él,(40). 
La perspicaz dama podia haber colocado en el mismo rango a los cabalistas, a los hipnotizadores, a los magos, a los magnetistas e imposturólogos, y, en cierto modo, bien que "servatis servandis", a algunos médicos afamados-como por ejemplo T. Tronchin (1704-81) o, en otro plano. A. Mesmer (1734-1815) -, cuyo influjo sobre sus elegantes e hipocondriacos clientes era tan decisivo, que sus diagnósticos y sus métodos terapéuticos eran tomados como dogmas de fe por aquellas gentes de "cualidad y buen tono", más crédulas que creyentes, aficionadas al maravillosísmo hasta el exceso, y capaces de transformar, con elegante frivolidad, unos remedios curativos en una moda social. Tal ocurrio entonces con el «magnetismo", que se puso de moda, y, como todas las modas bien montadas, fue "una rabia, y una furia» devastadora que produjo estragos(41). Aunque en un grado de intensidad mucho menor, pero extendido a un mayor número de personas, algo parecido sucedió en el XVIII con la hidroterapia y sus aplicaciones balnearias.

Esta era, en general, y muy a grandes rasgos, la dimención terapéutica y social-quiero decir elitista-de las estaciones termales de aquel tiempo, y por tanto no es necesario insistir en que sólo una minoría muy restringida podía beneficiarse de los remedios ofrecidos por tales establecimientos.

Aquí voy a limitarme a analizar el caso de Mme. de Krüdener (17641824), historiada dama rusa, que ejerció un gran influjo sobre don Simón de las Casas, embajador de España en Venecia, como más tarde lo ejercería poderosamente, según veremos, sobre el zar de Rusia Alejandro I (1777-1825).

La infatigable viajera Bárbara Juliana de Vietinghoff, hija del barón Otto Herman y de la condesa Ana de München, nació en Riga (Letonia) el 11 de noviembre de 1764. Nadie hubiera podido pensar entonces en la incoercible propensión hacia la mística proselitista que, años más tarde, manifestaría esta criatura, "romántica antes del Romanticismo" y utopista "iluminada" que, bajo el nombre de Mme. de Krüdener, pasaría no ya a la historia, sino a la gran Historia, pues fue ella quien, además de acuñar la expresión, le dio nombre e inspiró los principios metafísicos de la llamada Santa Alianza, sistema político-religioso de la Restauración cuyo máximo portaestandarte sería el zar Alejandro I de Rusia.

Desde niña, Bárbara dio muestras de tener una mente muy despierta y una gran pasión por los libros. Como correspondia al rango social de la familia a la que pertenecia - el barón Otto Herman era gobernador de Riga, y su abuelo materno era el mariscal de München-, recibió una esmerada educación; dentro de los principios religiosos luteranos, y a los quince años dominaba el alemán, el ruso y el francés, idiomas de los que tanto uso haria en el futuro. En 1776 emprendió, en compañia de sus padres, el primero de los innumerables viajes que trenzarian su asendereada vida. 
En esta ocasión se detuvo en varias ciudades alemanas, y, después de visitar detenidamente Londres, se asentó en París, donde permaneció hasta la primavera de 1782 .

La capital francesa era entonces el lugar ideal para poder relacionarse con espiritus brillantes, para estar al tanto de la literatura más vanguardista, y, en fin, para encontrar lo que brumosamente buscaba la temperamental letona. Por eso nos imaginamos que la joven Julia-como ella se hacia llamar - frecuentó los famosos "salones" parisinos, asistió a la ópera para escuchar la música de Gluck y de Piccini, y leyó los libros de moda, aunque sabemos de clerto que aprendió la danza con el maestro de baile Vestris. Pero lo que aqui nos interesa destacar es que Julia se puso en París en relación con dos personajes, cuyas ideas no sólo iban bien con su idiosincrasia mental (tal vez por eso las buscaba), sino que influyeron en la cristalización de sus tendencias "místicas» e incluso con su destino terrenal(42).

El primero de ellos fue el judio portugués Antonio Martínez Pasqualis (1715-79), teósofo y jefe de un grupo de iluminados, que llegó a París en 1778. Habia fundado una secta esotérica que se regia por los ritos cabalisticos; soñaba con la reconciliación del hombre con Dios, y pretendía encontrar todo el saber en la cábala judía. Aunque no adoptó su sistema por entero, el principal discipulo de este lusitano errabundo era entonces Claudio de Saint-Martin (1743-1803), filósofo iluminado y metafísico espiritualista, autor de los Rapports entre Dieu, l'Homme et l'Univers, obra en la que propugnaba el reinado de la armonia entre los hombres y las naciones, y que produjo no pequeña conmoción entre ciertas gentes crédulas, buscadoras de sucedáneos religiosos. Ambos trataban mucho en París con la duquesa de Borbón, hermana del lamentable Felipe Igualdad, duque de Orleans, y las doctrinas de Saint-Martin, que se difundieron por el centro de Europa, serian muy bien recibidas en los círculos de la nobleza de Estrasburgo a los que pertenecía la mencionada baronesa d'Oberkirch.

El otro personaje a que aludiamos fue el célebre-y ya citado-curandero alemán Mesmer, establecido en París en 1778, que pretendia sanar toda clase de enfermedades, sobre todo las nerviosas (recuérdese "La curación por el espíritu", de que nos habla S. Zweig), por medio del magnetismo, y provocaba éxtasis hipnóticos con su milagrosa varita. Su nombre andaba entonces en todas las bocas, y hasta la reina M. ${ }^{a}$ Antonieta, arrastrada por la curiosidad y la moda, llegó a consultarle una vez.

Abundan los relatos que describen las multitudes que solian acudir a la consulta del "doctor" Mesmer, sita en la plaza de Vendôme, donde se celebraban las famosas sesiones en las que participaban desde los príncipes y los nobles más encopetados hasta las cortesanas de trapío 
más lujoso, mientras que los criados esperaban en la antesala. El poeta André Chénier, el dudoso bajofondista Restif de la Bretonne, el general La Fayette, y el mismo Saint-Martin se apasionaron por el magnetismo, la hipnosis y el sonambulismo, que entonces hacian furor en las gentes.

Pero aparte de este aspecto sensacionalista, que le producia pingües ganancias, Mesmer-que llegó a hacerse rico de esta guisa-formó una pequeña capilla de adeptos, para pertenecer a la cual había que pagar de entrada la nada módica suma de cien luises(43). A este grupo esotérico de iniciados pertenecía el abogado lionés Bergasse, que dio al «mesmerismo" un carácter religioso, y fue él quien "evangelizó" con tales principios a la joven Julia, cuya devota gratitud a su iniciador jamás se desmentiria a lo largo de su vida.

La baronesa d'Oberkirch conoció personalmente al impostor Cagliostro, como conoció asimismo al tristemente célebre cardenal Luis de Rohan, enredado con aquél en el clamoroso "affaire du collier»; y también trató con Mesmer y con Saint-Martin, cuyas ideas le influyeron más de lo que ella misma se figuraba. Pues bien, esta dama linajuda que, además de gazmoña, era muy dada al esoterismo, anotaba el año 1778 en sus Mémoires: "Entonces se hablaba mucho en Estrasburgo de una mujer joven, de imaginación brillante y exaltada, que quería crear una secta y reformar las creencias filosóficas, ajustándose a los sueños (rêveries) de Swedemborg (44) y otros utopistas. Esta mujer era la baronesa de Krüdener. Su marido seguía la carrera diplomática y en 1768 fue embajador en Berlin(45). Mme. de Krüdener se limitaba entonces a medir sus fuerzas, y a propalar sus doctrinas en los salones, donde hacía muchos prosélitos con la ayuda de sus dos bellos ojos y de su espiritu fascinador. Yo no puedo menos de ver en ella una especie de Mmę. Guyon(46), y se me ha metido en la cabeza la idea de que terminará como ésta: creando una escuela y sufriendo persecucion. Es un alma ardiente y honesta, pero seducida por un falso sistema; se ha descarriado del camino y no sabe a dónde va, pero ella sigue siempre adelante y así se figura que asciende. Los espíritus exagerados, cuando no están sostenidos por unos principios seguros, no pueden acabar de otra manera»(47).

Este retrato, tan poco indulgente como falto de precisión, refleja, sin embargo, con gran nitidez los rasgos esenciales que caracterizaban-y caracterizaron más tarde-la fisonomía "mística" de esta mujer ardorosa que, ciertamente, fue cualquier cosa menos un ser vulgar; por lo que se refiere al triste final de Mme. Krüdener, la baronesa d'Oberkirch salió profeta.

Terminada su estancia en París, Julia regresó a su patria, y en septiembre de 1782 se casó, en el castillo de Ramkau (Livonia), con el barón Constantino de Krüdener (1744-1802), veinte años mayor que ella. 
Los nuevos esposos se instalaron en Mittau (Curlandia), donde el barón ejercia el cargo de embajador de Rusia, y en enero de 1784 Julia dio a luz su primer hijo, Pablo(48).

A finales de ese año el barón de Krüdener fue nombrado ministro plenipotenciario de Rusia ante la República de Venecia, a donde se dirigió con su familia. Después de atravesar Polonia y Bohemia, se detuvieron en la imperial Viena, y durante el camino, el nuevo secretario de la embajada rusa en Venecia, Alejandro de Stackhieff, que viajaba juntamente con ellos, se enamoró perdidamente-aunque sin consecuencias-de Mme. de Krüdener.

Parece que el nuevo destino agradó tanto a la joven embajadorá, deseosa de ponerse en contacto con la soleada Italia, y de disfrutar del embrujo de la vida veneciana, como desagradó a su marido, que se sintió un tanto relegado en este puesto; pero este sentimiento despechado da quizá la medida del escaso temple diplomático de la personalidad del barón, ya que el abate Bernis, más tarde cardenal y embajador de Francia en Roma durante casi un cuarto de siglo, refiriéndose precisamente a la embajada de Venecia, a la que fue enviado en 1752, escribia las siguientes lineas: "El ir destinado a la embajada de Venecia se mira bastante comunmente como una comisión poco importante; esto hace que las Cortes europeas no envien, desde hace mucho tiempo, embajadores muy hábiles para ocupar este puesto. Bien es verdad que esto no parece muy necesario, a la vista del poco influjo que la República de Venecia tiene en los asuntos generales de Europa. Esto no obstante, yo no conozco una escuela mejor que la embajada de Venecia para formar embajadores; nada es indiferente en aquel país: cada palabra, cada acción produce su efecto; de ese modo, un embajador atento y reflexivo se acostumbra a razonar todas sus gestiones y a no considerar nada como inútil. Por si fuera poco, en Venecia hay que tratar con un Gobierno invisible, y siempre por escrito, lo cual obliga a usar siempre de una gran circunspección para no enviar al Senado nada que no esté bien digerido y maduramente pensado (49).

La estancia de los Krüdener en Venecia, en la que Julia encontraba, sin embargo, "quelque chose de lugubre", se prolongó hasta diciembre de 1786, fecha en que el barón fue destinado con el mismo empleo a la embajada rusa de Copenhague. En la capital danesa comenzarian las desventuras de Julia, pero durante su tranquila estancia en Venecia es cuando Mme. de Krüdener conoció al embajador de España don Simón de las Casas (1742-98), que acababa de contraer matrimonio con una prima suya.

Este "vizcaino" instruido, y de familia bien acomodada, siempre estuvo protegido por el ministro de Estado, Floridablanca, que lo envió primero de secretario de embajada a Viena, y en 1781 de embajador a Berlín, donde trató de cerca al gran Federico II(50). El aragonés J. N. de Azara, agente de preces en Roma, decía de Casas, al que habia tratado en las covach.uelas 
ministeriales, que "el sol no calentaba mayor camueso que él». Hombre de genio cachazudo y tranquilo, fue destinado a Nápoles en enero de 1785, para sustituir en la embajada española de las Dos Sicilias al achacoso vizconde de la Herreria, cuya corta misión diplomática había constituido un rotundo fracaso. Pero tampoco le fue mejor a Casas, porque su mandato en Parténope apenas duró ocho meses, y después de sufrir los vejámenes más inauditos por parte de la reina $\mathrm{M}^{\text {a }}$ Carolina, tuvo que escaparse de Nápoles porque su vida peligraba. Su protector Floridablanca lo destinó entonces a la embajada de España en Venecia, a donde llegó el 14 de mayo de 1786 en compañia de su secretario Clemente Campos, que lo había sido en Nápoles, y que también habia tenido que salir de allí de mala manera después de cerrar la embajada.

El secretario Campos, a quien todo el mundo llamaba Campitos, por su exigua estatura y sus maneras afables, escribiendo a su protector el conde de Aranda, le decía: "Hace seis dias que estamos en este rarísimo país; V. E. que lo conoce confesará que en nada se parece a ningún otro de Europa, bien que no deja de ser muy respetable su constitución y gobierno. Andamos con nuestras capas negras de tafetán, esclavina y capucha de gasa, máscara y sombrero puesto; figúrese $V$. E. qué nuevo se nos hará este traje a los que sólo lo acostumbrábamos a llevar en Carnaval; V. E. sabe que todo el que tiene relación con el cuerpo diplomático acreditado en esta República no puede tratar absolutamente con la nobleza venecianas(51).

Remachando este último punto, referente al aislamiento en que vivían los miembros del cuerpo diplomático extranjero, escribia el propio Casas desde Parma: "Ni los embajadores, ni los secretarios de embajada, ni ningún comensal ni familiar del embajador puede tratar de palabra ni por escrito con ningún indivíduo de la nobleza veneciana de ambos sexos, con ninguno del orden de los Secretarios, ni con sus comensales y criados. Es sabida la vigilancia que hay en esto, los riesgos de la menor infracción, la suma dificultad de ocultarlas, y la severidad con que se castigan»(52).

Es cierto que este uso político tan original puso en frecuente contacto al embajador Casas y a Mme. de Krüdener, que se complacía en evocar en su Journal de Venise su asistencia a las alegres fiestas y saraos organizados por el conde de Rosemberg, embajador de Austria, y por el matrimonio Casas en su "Villa Pisani", casa de campo situada a orillas del Brenta, cerca de Padua(53); pero también es verdad que la separación entre los diplomáticos extranjeros y los nobles venecianos no era tan estricta y rigurosa como se blasonaba. Refiriéndose precisamente a esta extraña costumbre, escribía el experimentado abate Bernis las siguientes líneas: "No se debe creer a la letra que, aunque la nobleza veneciana no puede tener ninguna relación ("commerce») con los embajadores extranjeros (severidad muy sabia, pues si la República renuncia alguna vez a ella, perderá sus costumbres, y muy pronto alterará sus leyes: lo uno sigue a lo otro); no se debe 
creer-repito-que, a pesar de este rigor, los embajadores extranjeros no tengan cierta relación ("liaison") con los magistrados; se habla por terceros; muchas cosas se dicen por signos en la Opera, circunstancia que obliga necesariamente a los embajadores extranjeros a llevar máscara y a frecuentar los espectáculos; y entre ellos y los venecianos se crean incluso amistades vivas y constantes»(54).

A pesar de que el tono externo de su vida era banal y mundano, Mme. de Krüdener no olvidaba sus tendencias religiosas. El 2 de agosto de 1785 anotaba en su Journal: "J'eus le soir une conversation sérieuse avec mon mari au sujet de la Religion. Insensiblement, nous parlâmes du caractère. II me dit que j'avais une forte pente à l'enthousiasme, mais qu'avec tant de douceur que j'en avais, il n'y avait point de fanatisme à craindres(55).

A Julia le costaba muy poco aceptar el comentario halagador de su marido, y pintar su carácter-o un aspecto de su carácter-con tonos favorecedores, pero ello no invalida el hecho de que el entusiasmo puede ocultar un fanatismo larvado, y aunque así no sea, el entusiasmo suele ser muy a menudo contagioso, y con esta clase de trémolo es como Mme. de Krüdener solia hablar y expresarse en público. Basta leer algunas páginas de su Geraldine, escritas entre diciembre de 1789 y enero de 1790, para ver los transportes "misticos" con que esta mujer iluminada y ardiente describia-ya entonces-no sólo su mesianismo (de hacer el bien a los hombres y unirlos por el amor), sino la seguridad que sentia de creerse especialmente elegida por Dios misericordioso, que se había dignado sembrar en su mente y en su corazón tan sublimes intenciones.

Pero esta llamada mistica de Mme. de Krüdener no ardía solamente con resplandores celestiales; además de lo que tenía de aura sentimental, también despuntaba en sus manifestaciones la veta de una política misteriosa, pero reaccionaria "avant la lettre", entendiendo por tal entelequia una organización internacional regida por unos monarcas "religiosos", nutridos por las esencias más rancias del Antiguo Régimen, que fueran menos soberanos que hermanos de sus súbditos. En una palabra: la sublimación estática de la "res monarchica».

No es fácil saber con exactitud-dessunt acta-hasta dónde pudieron calar, y el influjo que pudieron ejercer sobre Casas las ideas político religiosas vertidas por el "entusiasmo" de Mme. de Krüdener en sus conversaciones-siempre en francés-con el embajador español en Venecia. Lo que sí conocemos muy bien es el comportamiento personal y la actitud política adoptada por Casas, tanto privada como diplomáticamente, a raíz del estallido de la Revolución Francesa. Su reacción ante tamaña convulsión fue a todas luces distinta de la que tuvieron los demás embajadores españoles acreditados entonces en las diferentes Cortes europeas. 
Porque Casas no sólo se pronunció como un antirrevolucionario radical, sino que se hizo realista a ultranza, y no contento con ayudar todo lo que pudo a los emigrados franceses, fugitivos de su patria, suministró abundante información a las potencias enemigas de la República Francesa, para lo cual no tuvo inconveniente en practicar el turbio papel de espía, y colaborar estrechamente con el conde d'Antraigues (1753-1812)(56), personaje de estampa aventurera (el conde d'Avaray, ángel negro de Luis XVIII, lo calificó de "fleur des drôles"), y cabeza de una extensa red de información, que acabaría sus días trágicamente, siendo apuñalado en Londres por un criado suyo que, según se dijo, estaba a sueldo del propio Luis XVIII.

Pase-e incluso es comprensible-que Casas mantuviera con este aventurero tal tipo de relaciones mientras ejercia el cargo político de embajador en Venecia(57), donde permaneció hasta 1795, año en que España dejo de ser enemiga de la República Francesa para hacerse su aliada por el tratado de Basilea (22 julio 1795), y Casas fue destinado a la embajada española de Londres; lo extraño y curioso es que este espionaje antirrevolucionario, del que Casas hizo una cuestion personal (y bien se quejaba de ello J. N. de Azara, embajador de España en Roma hasta 1798), lo siguio practicando privadamente-aunque siempre unido al espía d'Antraigues-cuando, concluida su corta legación en Inglaterra, volvió de nuevo a Venecia como persona particular y sin carácter diplomático alguno.

Pero volvamos de nuevo hacia atrás. Después de haber hecho un largo recorrido por la Península italiana, los Krüdener abandonaron Venecia y emprendieron el viaje hacia Copenhague en diciembre de 1786, pasando por Basilea y Frankfurt; de camino, Mme. de Krüdener-y el dato es altamente significativo-hizo un alto en Neuwied, para visitar alli a una comunidad de Hermanos Moravos(58), secta por la que Julia se sintio siempre muy atraida, como tendremos ocasión de verlo.

Tras dos años de riñas y reconciliaciones con su marido, en marzo de 1789 se consumó la ruptura del matrimonio Krüdener, y Julia, que se encontraba sentimental y físicamente agotada, abandono Copenhague con sus hijos y su hijastra Sofía, que siempre le sería fidelísima.

Después de pasar por París, donde vivió la jornada de la toma de la Bastilla y conoció a Bernardino de Saint-Pierre, celebrado autor de la romántica novela Paul et Virginie, del que quiso-en vano-hacer su confidente sentimental, Mme. de Krüdener (que jamás abandonaría el apellido de su marido) se instaló en Montpellier, y allí conoció a Adrián de LezayMarnesia (1770-1814). Este joven universitario, estudiante de botánica y traductor de Schiller en sus ratos de ocio, era cuñado del popularísimo P. C. de Beaumarchais, y tenia propiedades en la región del Jura. Las agitaciones campesinas le obligarian a emigrar de Francia, pero vuelto más 
tarde a su patria, fue nombrado en 1806 prefecto del Departamento de Mosela, y en 1812 del Bajo Rin. Allí se hizo muy amigo del pastor protestante Oberlin, famoso filántropo de Ban de la Roche, que propagaba las utopías del sueco Swedemborg, conocidas ya por Adrián a través de Mme. de Krüdener. Cuando el prefecto Lezay-Marnesia murio en octubre de 1814, Mme. de Krüdener se desplazó hasta Estrasburgo con el fin exclusivo de consolar a su viuda.

Pero este momento estaba todavía muy lejos. En agosto de 1789 , el joven Adrián se sentía enamoradísimo de Mme. de Krüdener, y parece ser que la baronesa, seis años mayor que él, le correspondía de una forma un tanto singular. Porque ha de saberse que Mme. de Krüdener, aparte de su marido con el que había contraido "un mariage de raison", tuvo a lo largo de su intensa vida varias clases de enamoramientos; unos, como el que sintio en 1791 por "su primer gran amor", Carlos Luis de Frégeville, o sobre todo el que tuvo por Claudio Hipólito Terray, que le hizo un hijo en 1798, fueron realmente tórridos; en cambio otros, como los que sintió por el mencionado Adrián Lezay, y por el diplomático napolitano Luis Laffredo, príncipe de Cardito (1758-1827), al que conoció durante su estancia en Copenhague, fueron más bien platónicos.

Mme. de Krüdener, que derramaba lágrimas religiosas en la iglesia de los Recoletos de Montpellier, y sus plegarias eran-como ella misma escribía el 2 de diciembre de 1789- «des transports de bonheur», encontraba en su piadoso recogimiento que "su pasión por Adrián no le espantaba como si fuera un crimen", antes muy al contrario, y ello era asi porque Julia confiaba siempre-son sus palabras- -en la Bondad Indulgente de Aquel que no castiga el mal no reconocido como talı.

Adrián tuvo que abandonar unos días Montpellier por asuntos familiares, y durante su corta ausencia Mme. de Krüdener le escribió en otoño de 1789 las siguientes palabras: "Mon ami, nous ne pouvons renoncer l'un à l'autre. L'Eternité entière ne peut limer la chaîne qui nous attache. Non, jamais l'amour n'a été conçu ainsi que par nous, jamais!. Ce concours de circonstances, et cette chaleur du bien qui était dans nos âmes, a pu se réunir à lui et lui donner un si énergique ressort».

Pero esta declaración amorosa no pasaba de platónica, y por serlo no era obice para que unas líneas antes le dijera: "J'ai abjuré à jamais la plus légère coquetterie, la vanité et l'emploi frivole de bien de moments; chaque jour doit être marqué par un pas vers le bien, et j'espère alier toujours en augmentant. Je travaille, et sans relâche; mes enfants, mes entours les plus indigents, tous doivent se ressentir de mes progrès; votre vue même n'otera pas un seul moment à mes devoirs. C'est ainsi que vous me trouverez, attendez-vous de ma part à de la rigueur et à la plus sévère attention à ne jamais enlever un instant à vos occupations. Je vous permets un peu d'épicureisme, mais prenez-y garde, assez pour répandre du charme sur la 
vie, assez pour en désirer toujours, mais qu'il soit semblable à la fleur délicate dont on supporte l'odeur agréable, pas à celle qui enivre et qu'on jette loin de soi quand ses funestes et trop violents parfums ont entêté,(59).

Teniendo en cuenta la idiosincracia-un tanto especial-de Mme. de Krüdener, tampoco debe olvidarse que en aquellos momentos todavía estaba viviendo las secuelas del reciente fracaso de su vida matrimonial. Este ideal, en el cual había cifrado todas sus esperanzas de joven sensible y de esposa apasionada, se habia venido abajo dejándole un sabor a ceniza. Pero al mismo tiempo se sentía la "ramante ideal», que sin renegar de la esposa ideal, $y$ haciendo un escudo defensivo de este contubernio de ideas $y$ sentimientos, esclavizaba a su joven enamorado Adrián, negándole toda consumación física y prometiéndole tan sólo una hipotética sublimación espiritual a base de continencia y de ascesis. Tales eran los designios de Mme. de Krüdener sobre Adrián; ella lo habia dispuesto así, pero su «misión» cubría mal y disimulaba peor su propio egocentrismo, que se confirmaba ante los deseos que ella misma provocaba en el joven enamorado, todo lo cual no tenía otra salida que el fracaso.

Todavía el 19 de diciembre de 1789, la baronesa escribía a su paciente adorador: "Ne me demandez pas de vous répondre sur la question que vous me faites, ne me demandez pas ce que ferais si un jour j'étais dans le cas de disposer de ma main, ne me le demandez. Je vous en conjure. Non, décider d'une question pareille, c'est penser de sang-froid à un événement affreux, et jamais je n'y penserai de sang-froid. Si je le pouvais, dès cet instant, je renoncerais à vous à jamais, mais je n'y puis penser sans frémir, comme je ne puis penser à vous quitters(60).

Como puede verse, la postura de Mme de Krüdener no dejaba lugar a dudas; era tan clara, y desvariada, como egoista: nada de casarse con Adrián, como éste habia aventurado ingenuamente; sólo el pensarlo le hacia temblar de horror; pero tampoco renunciar a él por completo, para tenerlo de ese modo a su lado como un perrillo faldero, y poder disfrutarlo alimentándolo con golosinas platónicas.

Aconsejada por los médicos, Mme. de Krügener siguio las huellas de Boudon de Saint-Amans, haciendo un "viaje sentimental» a la estación termal de Barèges, en los Altos Pirineos, donde permanecio desde junio hasta septiembre de 1790 en compañía de Adrián, que durante sus paseos por los alrededores pudo ejercitar sus aficiones de herborista, mientras Mme. de Krüdener prefería quedarse en el poblado y seguir trenzando sus abizarras ideas", que destruyeron por completo su no menos bizarra relación con el joven botánico, cada vez más reacio a convertirse en neófito de una catequesis tan utópica e irreal como insípida(61).

Rotas, pues, definitivamente sus relaciones en Barèges, Mme. de Krüdener volvió con sus hijos a Montpellier, donde se consolo muy pronto de 
este fracaso sentimental, pues antes de la primavera de 1791 se habia encontrado con el apuesto Carlos Luis de Frégeville, su "primer gran amor", cuyos hechizos transformaron como por arte de magia sus elevados deliquios místicos con unos ardores más a ras de tierra. "Qui fait l'ange, fait la bête!" es, como todos saben, una frase del perspicaz Blas Pascal.

A partir de entonces comenzo la vida giróvana de Mme. de Krüdener, a la que encontramos en Bruselas, Hamburgo, Koenigsberg (donde se separó de su amante Frégeville), Riga y San Petersburgo, a donde se dirigió para asistir a la muerte de su padre. En otoño de 1793 conoció en Leipzig al emigrado francés Claudio Hipolito Terray, cuyos padres habian sido guillotinados en París, y a las pocas semanas de relación con él estableció una especie de "matrimonio secreto", según comunicó ella misma a su madre. En 1795, Terray se instaló en Lausana; entonces, Mme. de Krüdener pidió el divorcio a su marido, sin impetrarlo, y comenzó a corresponderse epistolarmente con el príncipe de Cardito, diplomático napolitano al que escribia largas cartas sentimentales.

En 1797 se fue a las caldas de Aix-les-Bains, muy visitadas por los ingleses, $y$ allí volvió a reunirse con Terray. Fueran o no prolificas las virtudes de aquellas aguas termales, el caso es que, en febrero de 1798, Mme. de Krüdener dio a luz un niño que fue bautizado con los mismos nombres que su padre Claudio Hipólito, y muy pronto sería llevado a Ginebra para ser confiado a los cuidados de una experta institutriz. Mme. de Krüdener vivió siempre separada de esta criatura a la que apenas prestó atención, pero ello no fue impedimento para que, a imitación del autor de Emile, que mandó a sus cinco hijos a la inclusa, también ella comenzara en 1779 la redacción de un tratado de educación titulado Elisa ou l'éducation d'une jeune fille; ni para que, aprovechando un viaje a Riga por cuestiones de herencia, se detuviera en Gnadenfrei, sede de una comunidad de Hermanos Moravos, cuya vida compartió durante algunas semanas.

El verano de 1800 se reunió en los baños de Teoplitz con su anciano marido, el barón de Krüdener, que había sido nombrado embajador de Rusia en Berlín, pero no espero a su muerte (que ocurriria en junio de 1802) para separarse nuevamente de él-esta vez de una forma definitiva-, y marcharse a París, donde empezó a codearse con Mme. de Staël, Benjamin Constant, Joubert y Chateaubriand, que acababa de publicar el Génie du christianisme(62).

Cuando Mme. de Staël fue expulsada de París por el cónsul Bonaparte, Mme. de Krüdener se fue a vivir a Lyon, desde donde siguió correspondiéndose con el príncipe de Cardito. En 1803 publico en París Valérie, novela que alcanzó un gran éxito, pero sin tiempo para disfrutar de él, abandono repentinamente la capital francesa para refugiarse en Koenigsberg, donde permaneció hasta 1807 sin apenas moverse de alli. Durante este largo retiro se adentró en las vías místicas, poniendo un irrevocable punto 
final a sus devaneos sentimentales (la baronesa tampoco era ya una niña, pues frisaba los 43 años de edad), y el invierno de 1807 marchó a Herrnhut, con su hija Julia, para pasar allí una temporada con los Hermanos Moravos.

Durante los años siguientes, Mme. de Krüdener entraría en contacto con miembros de otras sectas, y conocería al filantrópico pastor Oberlin (relacionado, como dijimos, con Adrián de Lezay-Marnesia), que le ayudó a formar una misión-asi llamaba la baronesa a su "capilla"-, cuyos miembros se establecieron en un pueblecito cerca de Stuttgart; pero a los tres meses de permanencia allí el rey Federico I de Wurtemberg les ordenó salir de sus dominios por considerarlos peligrosos y perturbadores de la paz. Mme. de Krüdener se sometio, y a continuación marchó a Baden, donde entró en relación con la reina Hortensia de Beauharnais, esposa de Luis Bonaparte, pero tuvo que marcharse precipitadamente a Riga, para asistir a su madre que murió en enero de 1811, dejando a su hija una herencia nada despreciable. A su regreso se detuvo un tiempo con los Hermanos Moravos de Gottesberg (Silesia), y después de pasar por Dresde, Weimar y Carlsruhe, se reunió en Ban de la Roche con su venerado pastor Oberlin.

Los años 1812 y 1813 fueron para Mme. de Krüdener un tiempo de contínuas idas y venidas para instalar una "colonia cristiana" en las cercanías de Heidelberg(63). En uno de estos viajes entró en contacto con la zarina Isabel, y a través de ella con el zar Alejandro I, trece años más joven que Mme. de Krüdener, la cual tuvo entonces con el monarca ruso varias entrevistas, que a veces duraban horas y horas (llegando a producir celos en la zarina), y en julio de 1815 lo siguió a París, donde el 23 de septiembre el zar Alejandro I presentó a sus "hermanos», el rey de Prusia y el emperador de Austria, el texto de la Santa Alianza, que se firmo el 26 del mismo mes. Esta jornada marco el zénit de Mme. de Krüdener, no menos que el comienzo de su ocaso.

A continuación, Mme. de Krüdener pasó nuevamente a Baden, cuya municipalidad (ya no estaba allí su amiga Hortensia de Beauharnais) le prohibió reunir asambleas y predicar "la buena palabra". A lo largo de 1817 comenzo a sentirse perseguida, y no encontrando refugio seguro en ninguna parte pidio al zar Alejandro I permiso para establecerse en Rusia con sus adeptos, pero al llegar a la frontera la policía rusa la admitió a ella, prohibiendo la entrada a los demás acompañantes. Separada de éstos, Mme. de Krüdener se retiró a Mittau, y desde alli escribió al príncipe Galitzin, ministro ruso de cultos, una larga carta en la que explicaba cuál era el sentido de su "misión", y cómo debía interpretarse el texto de la Santa Alianza. Este paso le deparó una nueva entrevista con el zar, que tuvo lugar en septiembre de 1819, pero la baronesa no obtuvo nada que concerniera favorablemente a su "capilla". Al año siguiente escribio un tratado Sur l'éducation des princes, que dedicó a Alejandro I, al tiempo que le instaba 
a ayudar a los griegos, en lucha contra los turcos para alcanzar la independencia de su país; pero el zar no le prestó oidos, aunque en septiembre de 1821 le concedió una última entrevista, que fue secreta.

En mayo de 1822, Mme. de Krüdener recibió la orden de abandonar San Petersburgo, y en agosto de ese mismo año se promulgó un "úkase» por el que se prohibia en Rusia la existencia de todas las sectas y sociedades secretas, fueran religiosas o no. Mme. de Krüdener hizo todo lo posible para prolongar su estancia en la ciudad del Neva, a fin de ver nuevamente al zar, quien después de muchas vacilaciones no se atrevió a recibirla, porque temía al clero ruso y a la policia, hostiles a las ideas de esta mujer, cuyo ascendiente sobre Alejandro I temian.

En mayo de 1824, Mme. de Krüdener, su hija Julia y el marido de ésta, Francisco de Berckheim, se embarcaron en San Petersburgo con la intención de establecerse en Crimea, para fundar alli una "colonia cristiana». Durante la travesía, que no fue nada fácil, Mme. de Krüdener se sintió desfallecer, de suerte que a poco de llegar a Korasoubazar, su último asilo terrenal, se sintió gravemente enferma, y el 13 de diciembre de 1824, a los 60 años de edad, y rodeada de un puñado de adeptos, entregó su alma al Dios de la Indulgencia.

\section{NOTAS:}

(1) Estas páginas constituyen la parte final de una comunicación titulada: Viajeros españoles del siglo XVIII en los balnearios del Alto Pirineo francés, que el autor presentó en el "Coloquio de Paun (26-30 de mayo de 1981).

(2) L. FERNANDEZ DE MORATIN, Obras póstumas (2 vols.). Madrid, Rivadeneira (1867-68) t. I, pp. 293-94. «Día 23 de agosto de 1793. Las sillas de posta de Ostende a Suiza son de lo más indecente e incómodo que puede imaginarse, muy semejantes a nuestras calesas: regularmente son de cuatro ruedas; viejas, sucias, desabrigadas, llenas de remiendos y apósitos(...); los postillones, del todo execrables: lerdos, sordos, embusteros, estafadores a no poder más".

(3) Ibidem, t. I. p. 317. "Dia 18 de septiembre de 1793. Pasé de Fiorenzuola(...). Iba leyendo en mi carricoche, bien ajeno de toda desgracia; me ocurre mirar por la ventanilla de la trasera, y me encuentro sin cofre: pié a tierra; desata el postillón uno de los caballos, corre más de media legua, y vuelve con la plausible noticia de que el cofre no aparece, esto es, que he perdido, además de mi ropa, mis apuntaciones diarias de trece años a esta parte, las cuentas de mis intereses en España, las recomendaciones para los Embajadores, las observaciones hechas en mis viajes por Francia, Inglaterra, Flandes, Alemania (...) el trabajo de todo un año, obras manuscritas y qué sé yo qué más: si esto es bastante para hacer desesperar a cualquiera, nadie extrañará la desesperación en que me vi».

(4) A. MOUSSET, Un témoin ignoré de la Révolution: le comte Fernán-Núñez, ambassadeur d'Espagne à Paris (1787-1791). París, E. Champion, 1924.

(5) Fernán-Núñez a Floridablanca. Bayona, 14 de septiembre 1787. AHN (Archivo Histórico Nacional, Madrid), Estado, leg. ${ }^{\circ}$ 4.640; B. d'OBERKIRCH, Mémoires. París, Mercure de France (1.979), p. 143. "Le 15 (de mayo de 1782) nous couchâmes à Dormans (...). Depuis Saint-Dizier, il pleuvait sans cesse, et les chemins étaient abominables. J'avais les cơtes brisés de cahots, bien que notre voiture fût excellente». 
(6) FERNANDEZ DE MORATIN, o. c. t. I., pp. 521-22.

(7) Ibidem, pp. 538-40.

(8) A. de TILLY, Mémoires. París, Mercure de France (1965) p. 345.

(9) OBERKIRCH, o. c. pp. 230-31. "Cette Basse-Bretagne-escribía la baronesa el 29 de junio de 1782-est un pays affreux (...). On trouve de tout à manger dans ce pays, mais c'est si mal apprêté, tout y est si sale, qu'on mange point $n$; L. S. MERCIER, Le tableau de Paris. Paris, Maspero (1979) pp. 183-85. De lo caro y mal que se comia, de 1781 a 1788, en los restaurantes populares de Paris.

(10) FERNANDEZ DE MORATIN, o. c. t. I, pp. 538-40.

(11) R. OLAECHEA, José $/ /$ y J. N. de Azara. Los dos viajes del emperador austriaco a Roma. En «Miscelánea Comillas», t. 45 (Comillas, 1964) pp. 1-81.

(12) OBERKIRCH, o. c. p. 94. «Je parle ici de l'empereur Joseph II pour la première fois-escribia la baronesa en 1777-, et nous le retrouverons encore plus loin (...). Ses habitudes et sa vie ne se ressemblaient à celles de personne. Il couchait sur une paillasse recouverte d'une peau de cerf".

(13) . A. d'AVENEL, Les moyens de transport depuis sept siècles. En "Revue des Deux Mondes", t. II (Paris, 1913) p. 827.

(14) MERCIER, o. c. pp. 39-40, 263.

(15) N. ElIAS, La civilisation des moeurs. Paris, Calman-Lévy (1972) p. 221; Mme. de KRUEDENER, Lettres de voyage de Lyon à Paris (1803). Apud R. DERRÉ, Ecrits intimes et prophétiques de Mme. de Krüdener (1785-1807). París, CNRS (1975). «Lady B., après s'être placée ce matin comme de coutume à cóté de moi dans la berline, a rejeté sa tête en arrière, car elle aime à se tenir droite et cela lui réussit malgré les cahots de la voiture; puis, elle a tiré son mouchoir, l'a déployé lentement, a pris du tabac (rapé), et ensuite a craché hors de la portière avec le plus grand sang-froid du monde. Or, il faut vous dire que dans ce moment nous passions sur un pont, que sur ce pont passait un passant, et que Milady, comme si elle l'avait fait exprès, lui a craché droit sur le nez".

(16) MERCIER, o. c. pp.80-81, 214. La sensible Mme. de Necker vio que en una sala del hospital parisino de Bicêtre, que apestaba, se amontonaban en un mismo lecho seis miserables enfermos, embadurnados de sus propios excrementos. Ante tal espectáculo, "Mme. Necker puso en juego todo el crédito de que gozaba para hacer construir lechos en los que no se acostaran más de dos personas". Lo mismo ocurría en el hospital "Hótel-Dieu" de París.

(17) R. FOULCHE-DELBOSC, Bibliographie des voyages en Espagne et Portugal. (Paris, 1896); A. FARINELLI, Viajes por España y Portugal (3 vols.). Roma-Florencia, 1942-44; J. GARCIA MERCADAL, Viajes de extranjeros por España y Portugal (3 vols.) Madrid, Aguilar, 1962. El tomo III corresponde al siglo XVIII. En enero de 1745 aparecieron "Chez F. Didot" los dos primeros volúmenes de la Histoire générale des voyages, del abate Prévost, a los que seguirian trece más; el último volumen se publico en 1759.

(18) OBERKIRCH, o. c., p. 333.

(19) TILLY, o. c., p. 329.

(20) L. STERNE, A sentimental journey through France and Italy. Londres, Penguin Books (1967) pp. 34-35.

(21) M. PEZAl, Observations générales sur les voyages (4 vols.). París (1783) t. IV, p. 5.

(22) J. J. ROUSSEAU, Oeuvres Complètes (3 vols.). París, Ed. Seuil (1971) t. III, p. 308; J. CADALSO, Los eruditos a la violeta. Madrid, Aguilar, Crisol, Ed. de J. L. Aguirre (1951), pp. 115 ss. Instrucciones dadas por un padre anciano a su hijo que va a emprender sus viajes. 209.

(23) F. ALVAREZ REQUEJO, El conde de Campomanes. Su obra histórica. Oviedo (1954) p.

(24) Ibidem, p. 25, n. $^{\circ} 47$ y 48.

(25) FLORIDABLANCA, Obras originales. Madrid, BAE (1912) t. 59, pp. 282, 295 y 330; R. OLAECHEA, El reino de Navarra en el siglo XVIII. Pamplona (1980) pp. 15, 16, 68-70. 
(26) Una legua equivalia a unos $5 \mathrm{kms}$.

(27) FLORIDABLANCA, o. c., pp. 297, 300-301.

(28) J. PUENTE, La visión de la realidad española en los viajes de don Antonio Ponz. Madrid, Moneda y Crédito, 1968.

81.

(29) G. GOMEZ DE LA SERNA, Los viajeros de la llustracion. Madrid, Alianza (1974) pp. 72 -

(30) J. SARRAILH, Voyageurs français au XVIII siècle: de l'abbé de Vayrac à l'abbé Delaporte. En «Bull. Hispanique», t. 36, Burdeos, 1934.

(31) J. SARRAILH, La España ilustrada de la segunda mitad del siglo XVIII. México, FCE (1957) pp. 290-338, 339-374.

(32) Véase la nota $n .^{\circ} 1$, en la que se indica que la comunicación sólo se refiere a "viajeros españoles", con la excepción de la rusa Mme. de Krüdener, por la relación que tuvo esta viajera con el embajador de España en Venecia, don Simón de las Casas.

(33) J. A. FERRER BENIMELI, El conde de Aranda y su defensa de España. Refutación del "Viaje de Figaro a España". Madrid-Zaragoza, 1972; Mémoires d'une femme de qualité sur le consulat et l'empire. París, Mercure de France (1966) pp. 342-43.

(34) A. LABORDE, Itinéraire descriptif de l'Espagne (6 vols.). Paris (1834) t. I, pp. 207 y 169; J. J. ROUSSEAU, o. c., t. III, pp. 281-82, 306-7.

(35) R. OLAECHEA, Las relaciones hispano-romanas en la segunda mitad del siglo XVIII (2 vols.). Zaragoza (1965) t. I, pp. 297-336.

(36) J. VIERA CLAVIJO, Viajes a Francia, Flandes, Italia y Alemania por los años de 1777 a 1781. Santa Cruz de Tenerife, 1849.

(37) SARRAILH, La España... o. c., pp. 353-54.

(38) M. VILLAURRUTIA, Fernán Núñez, el embajador. Madrid (1931) p. 13.

(39) MERCIER, o. c. pp. 278-80.

(40) OBERKIRCH, o. c. p. 334; P. HAZARD, El pensamiento europeo en el siglo XVIII. Madrid, Guadarrama (1958) pp. 137, 320-23, 359.

(41) OBERKIRCH, o. c. p. 495. La baronesa escribia en 1789: "La fin de ce siècle si incrédule est marquée de ce caractère incroyable d'amour du merveilleux, je dirais de superstition, si je n'en étais moi-même imbue, quoique malgré moi, ce qui dénote, assure-t-on, une société en décadence. II est certain que jamais les rose-croix, les adeptes, les prophètes et tout ce qui s'y rapporte, ne furent aussi nombreux, aussi écoutés. La conversation roule presque uniquement sur ces metières; elles occupent toutes les têtes; elles frappent toutes les imaginations, même les plus sérieses..."; MERCIER, o. c., pp. 259, 268-69. Señala que a mediados del siglo toda dama de "cualidad" tenia su "geometra"; y hablando del culto al maravillosismo que daban los parisinos, añadia: "On ne dipute plus nulle part sur la religion. C'est un vieux procès définitivement jugén.

(42) En 1798, Mme. de Krüdener visitaría en Zurich al fisiognomista e inventor J. G. Lavater (1741-1801)

(43) M. DEFOURNEAUX, Pablo de Olavide ou l'Afrancesado (1725-1803). París, PUF (1959) pp. 408-9; OBERKIRCH, o. c. p. 333.

(44) M. Swedemborg (1688-1772), hijo natural de la reina Ulrica de Suecia, fundó una secta ecumenista, pero sus adeptos formaron la llamada iglesia de Jerusalén; OBERKIRCH, 0 . c. p. 490 .

(45) El barón de Krüdener no fue embajador en Berlín hasta el año 1800.

(46) En septiembre de 1808, Mme. de Krüdener se relacionaría en Ginebra con los pastores Cellérier y Mouliné, y con aigunos miembros de la secta de las "Almas Interiores", que habia sido fundada por el caballero Dutoit-Membrini, discípulo de Mme. Guyon y autor de La philosophie divine, obra de espiritualidad aparecida en 1793. Véase F. MALLET-JORIS, Jeanne Guyon. Paris, Flammarion, 1978. Fuera de algún mínimo aspecto puramente anecdótico, no hay posibilidad de comparación entre Mme. de Krüdener y Mme. Guyon. 
(47) OBERKIRCH, o. c. p. 490 . Este texto parece haber sido reelaborado por los editores que publicaron estas Memorias muchos años después de muerta la baronesa d'Oberkirch.

(48) F. LEY, Mme. de Krüdener et son temps. Paris, PIon, 1961. En julio de 1787 daria a luz a su hija Julia; el barón tenía a su vez una hija, Sofía, de un matrimonio anterior.

(49) Cardl. de BERNIS, Memoires. Paris, Mercure de France (1980) pp. 116-17.

(50) Kaunitz-Quetemberg a Kaunitz. Madrid, 28 abril 1.780. Apud Berichte der diplomatischen Vertreter des weiner Hofes aus Spanien in der Regierungszeit Karls III. Madrid, C.S.I.C. (1979, t. VIII, p. 33; Kaunitz-Rietberg a Kaunitz. S. Ildefonso, 27 de agosto 1781. Ibidem, t. VIII, p. 303. Se revoca el destino de Simón de las Casas a Toscana, para enviarlo a Berlín, gracias a las influyentes gestiones del general O'Reilly y de don Simón de Aragorri, marqués de Iranda, rico comerciante, tío de Casas.

(51) Campos a Aranda. Venecia, 20 de mayo 1786. AHN, Estado, leg. ${ }^{\circ} 2.847$.

(52) Casas a Floridablanca. Parma, 2 septiembre 1786. AGS (Archivo General de Simancas), Estado, leg. ${ }^{\circ} 5.795$. Esta costumbre hacía que, en general, los miembros del cuerpo diplomático extranjero trataran con frecuencia entre si.

(53) Ch. EYNARD, Vie de Mme. de Krüdener (2 vols.). Paris,. Cherbuliez (1849) t. 1, p. 15.

(54) BERNIS, o. c., pp. 124-25. En su despacho del 21 de agosto de 1754, escribía Bernis desde Venecia: "J'entretiens un commerce sécret avec les principales familles de la noblesse; mais la plus importante de mes liaisons est avec $\mathrm{M}$. le procurateur Emmo, le premier homme de cette République, malgré son grand âge...".

(55) DERRÉ, o. c., p. 63. El subrayado es mio.

(56) L. PINGAUD, Un agent secret sous la Révolution et l'Empire: le comte d'Antraigues. París, Plon, 1894; J. GODECHOT, La contre-révolution, 1789-1804. Paris, PUF (1.961) pp. 186-215; Duc de CASTRIES, La vie quotidienne des émigrés. París, Hachette (1966) pp. 216-21.

(57) J. CHAUMIE, Les rélations diplomatiques entre l'Espagne et la France: de Varennes à la morte de Louis XVI. Burdeos (1957) pp. 34-35; IDEM. La corréspondance de Las Casas et du marquis de Bombelles, ambassadeurs de France et d'Espagne à Venise sous la Révolution. Paris, Pedone, 1952.

(58) Secta protestante husita surgida en Bohemis tras la muerte de Juan Huss (1415). Sus miembros admiten los artículos de la fe, si bien dentro de una total libertad de conciencia por parte del creyente. Esta secta se extendió por el centro de Europa, llegando hasta América del Norte.

(59) DERRÉ, o. c., pp. 112 y 110-11.

(60) Ibidem, p. 126.

(61) BOUDON DE SAINT-AMANS, Fragmen(t)s d'un voyage sentimental et pittoresque dans les Pyrénées. Metz, 1789. Este episodio de "platonismo sentimental» trae a la memoria (por sus semejanzas) el romance platónico vivido el verano de 1825, en Cauterets, por Jorge Sand (1804-76) con el joven bordelés Aureliano de Sèze. Véase A. MAUROIS, Lélia ou la vie de George Sand. Paris, Marabout-Hachette (1952) pp. 79-87.

(62) F. LEY, Bernardin Saint-Pierre, Mme. de Staël, Chateaubriand, Benjamin Constant et Mme. de Krüdener. Paris, 1967.

(63) Mémoires d'une femme de qualité... o. c., pp. 362 y 382. Relaciones de Mme. de Krüdener con la reina Luisa de Prusia, y el ministro prusiano Hauwigts, que era un «iluminadon. 